medRxiv preprint doi: https://doi.org/10.1101/2020.03.25.20043927; this version posted April 20, 2020. The copyright holder for this preprint

(which was not certified by peer review) is the author/funder, who has granted medRxiv a license to display the preprint in perpetuity.

It is made available under a CC-BY-ND 4.0 International license .

\title{
Dangers of ACE inhibitor and ARB usage in COVID-19: evaluating the evidence
}

Krishna Sriram* Ph.D. and Paul A. Insel*^ M.D.

Departments of Pharmacology* and Medicine^

University of California San Diego

La Jolla, California 92093, USA

Corresponding author:

Paul A. Insel, M.D.

Department of Pharmacology, MC 0636

9500 Gilman Dr.

La Jolla, CA 92093 USA

Email: pinsel@health.ucsd.edu

Mobile phone: 858-472-1817

Keywords: COVID-19, Angiotensin Receptor Blockers, ACE Inhibitors, Angiotensin II, ACE2

\section{Funding Information}

Support was provided by the Academic Senate of the University of California, San Diego

\section{Conflicts of Interest}

None 
medRxiv preprint doi: https://doi.org/10.1101/2020.03.25.20043927; this version posted April 20, 2020. The copyright holder for this preprint (which was not certified by peer review) is the author/funder, who has granted medRxiv a license to display the preprint in perpetuity. It is made available under a CC-BY-ND 4.0 International license .

\section{Abstract}

Background: Concerns have been raised regarding the safety of Angiotensin Converting Enzyme Inhibitors (ACEIs) and Angiotensin Receptor Blockers (ARBs) in patients with COVID-19, based on the hypothesis that such medications may raise expression of ACE2, the receptor for SARS-CoV-2.

Methods: We conducted a literature review of studies $(n=12)$ in experimental animals and human subjects $(n=12)$ and evaluated the evidence regarding the impact of administration of ACEls and ARBs on ACE2 expression. We prioritized studies that assessed ACE2 protein expression data, measured directly or inferred from ACE2 activity assays.

Results: The findings in animals are inconsistent with respect to an increase in ACE2 expression in response to treatment with ACEIs or ARBs. Control/sham animals show little to no effect in the plurality of studies. Those studies that report increases in ACE2 expression tend to involve acute injury models and/or higher doses of ACEls or ARBS than are typically administered to patients. Data from human studies overwhelmingly imply that administration of ACEls/ARBs does not increase ACE2 expression.

Conclusion: Available evidence, in particular, data from human studies, does not support the hypothesis that ACEI/ARB use increases ACE2 expression and the risk of complications from COVID-19. We conclude that patients being treated with ACEls and ARBs should continue their use for approved indications.

\section{Introduction}

There has been much recent debate regarding the use of ACE inhibitors (ACEIs) and Angiotensin Receptor Blockers (ARBs) in COVID-19 patients ${ }^{1-7}$, thus prompting concern among patients and health care providers. The basis of this concern involves whether ACEIs/ARBs increase expression of ACE2, the primary cellular receptor for the SARS-CoV-2 virus, thereby possibly increasing severity of the infection. Published correspondences/letters such as those cited above typically make assertions on a relationship between ACEI/ARB use and ACE2 expression levels but lack a detailed, comprehensive breakdown of available data in humans and animals. The strength of the experimental data is thus unclear regarding ACEI/ARB use and ACE2 protein expression.

To address this issue, we have reviewed key literature by assessing studies conducted in experimental animals (primarily rats) and humans, in order to obtain a more comprehensive picture of what the available data convey. We focus our discussion on studies for which ACE2 protein data are available (either via direct measurement or inferred from ACE2 activity assays), as tissue ACE2 mRNA expression appears to only weakly correlate with protein expression, as shown from data in the Human Protein Atlas ${ }^{8}$ (proteinatlas.ora), results from human renal samples ${ }^{9}$ and studies in experimental animals (discussed below [e.g., ${ }^{10,11}$ ]).

We identified relevant studies by searches in Pubmed and Google Scholar for all available literature. Combinations of search terms were used to maximize the identification of relevant studies. Search terms included "ACE inhibitor", "Angiotensin Receptor Blocker", "ACE inhibition", "ACE2", "ACE2 expression", "ACE2 protein expression", "ACE2 activity", "humans", "patients", "lung”, "heart", "kidney". We imposed no limits on when studies were performed. We manually curated each relevant hit to ensure the data were from articles with original research and/or meta-analysis and included quantitative/normalized ACE2 protein expression/activity and involved studies with tissues relevant to COVID-19/SARS-CoV-2 infection. 
medRxiv preprint doi: https://doi.org/10.1101/2020.03.25.20043927; this version posted April 20, 2020. The copyright holder for this preprint (which was not certified by peer review) is the author/funder, who has granted medRxiv a license to display the preprint in perpetuity. It is made available under a CC-BY-ND 4.0 International license .

\section{$\underline{\text { Results }}$}

We focused our assessment on studies that evaluated ACE2 levels in tissues/cells involved in infection by SARSCoV-1 or SARS-CoV-2. Data from 12 animal studies are summarized in Table 1, which shows the effect of ACEI/ARB use on ACE2 protein expression/activity in animals (primarily rats). We used conversion factors based on the principles of allometric scaling to evaluate doses in animals relative to their use in humans ${ }^{12}$. For studies in which this was relevant, we used the HED (Human Equivalent Dose, assuming a $60 \mathrm{~kg}$ human ${ }^{12}$ ) for doses of ACEI/ARBs. The conversion factor for rats was 6.2 (i.e., doses in $\mathrm{mg} / \mathrm{kg}$ were divided by 6.2 , then multiplied by 60 $\mathrm{kg}$ for a human equivalent dose) and 1.1 for pigs. We obtained recommended doses for humans using approved labelling from the Food and Drug Administration (FDA) website (fda.gov). These recommended human doses are provided in Table 2. For most of the drugs, the maximum doses indicated in Table $\mathbf{2}$ are generally not administered to humans, such that treatment of animals with equivalent (or larger) doses, (especially in models of acute dosing, as in refs ${ }^{17}$ and ${ }^{21}$ discussed in Table 1 ) raise concern about their relevance to ACEl/ARB administration to patients.

In summary, 3 studies ${ }^{10,13,21}$ in animals reported an increase in all treatment groups, of ACE2 protein expression/activity with ACEI/ARB treatment but in one such study, ${ }^{10}$ combined ARB/ACEl treatment did not show this effect. The other two studies reported relatively small effects $<40 \%$ increase in ACE2 protein expression in control/sham animals). All of these studies used high doses of ACEls/ARBs, as noted above. By contrast, 6 studies ${ }^{11,14,16,18,19,22}$ found little or no change in ACE2 expression with ACEI/ARB treatment. In 3 studies ${ }^{15,17,21}$, treatment with ACEI/ARB had no effect or a decrease in ACE2 protein expression/activity in control/sham animals; increased ACE2 expression was only observed following experimental exposure, such as lung injury, myocardial infarction, etc. In nearly all studies that reported an increase in ACE2, doses of ACEIs/ARBs used were greater than equivalent doses typically administered to patients. We identified only one study ${ }^{15}$ in which ACEI/ARB use increased ACE2 protein expression at doses typically used to treat patients, albeit these changes only occurred after exposure to acute injury (subtotal nephrectomy). Overall, the studies with experimental animals do not provide consistent evidence for an effect of ARB/ACEI administration on ACE2 protein expression, especially in contexts that model drug administration in humans.

A challenge with assessing the animal studies in Table $\mathbf{1}$ is that while doses were provided for the drugs, pharmacokinetic studies were not performed to ascertain peak serum concentrations $\left(C_{\max }\right)$ and Area Under the Curve (AUC), which would allow more precision in evaluating the translational relevance of findings. However, data from other studies provide insight into the pharmacokinetics in rats, at doses comparable to those used in the studies in Table 1. Table 2 shows estimates for $C_{\max }$ for the drugs used in studies in Table 1, in humans (at therapeutic doses, as indicated) and rats (at doses comparable to those in Table 1). The differences in AUC for these drugs between humans and rats mirror differences in $C_{\max }$; we refer readers to the indicated references for further details. With the exception of a study in a nephrectomy model ${ }^{15}$, animal data (including all data for control animals) that show a relationship between ACE2 expression and use of ACEls/ARBs involved drug treatments associated with plasma concentrations far in excess (often more than one order of magnitude) of values normally seen in patients. Absent exposure-response studies with more clinically appropriate drug concentrations, we conclude that the bulk of the animal data regarding ACE2 expression with ACEI/ARB administration has dubious translational relevance.

Evidence of changes in ACE2 protein in human subjects/patients (Table 3) are derived from studies that assessed ACE2 protein concentration or enzymatic activity in urine or serum/plasma. Of the 11 studies summarized in Table 3, 7 showed no effect of ARB/ACEI use on ACE2 protein levels in any conditions/patient grouping. One study ${ }^{37}$ documented a small increase in serum ACE2 attributable to use of ACEls among Type-1 diabetic patients 
medRxiv preprint doi: https://doi.org/10.1101/2020.03.25.20043927; this version posted April 20, 2020. The copyright holder for this preprint (which was not certified by peer review) is the author/funder, who has granted medRxiv a license to display the preprint in perpetuity. It is made available under a CC-BY-ND 4.0 International license.

but found no effect from use of ARBs. Another study ${ }^{34}$ found a slightly larger proportional decrease in urinary ACE2 in patients with Type-2 diabetes using ACEls/ARBs but did not distinguish between effects from use of ACEIs or ARBs. In one study ${ }^{33}$ the investigators observed that subjects using the ARB olmesartan had increased ACE2 levels, but several other ARBs and ACEls had no effect. In one study ${ }^{39}$, ACEl use had no effect in control, stage 3-5 chronic kidney disease patients or those on dialysis; ARB only had a small effect in patients on dialysis. Besides these quantitative data, another study used immunohistochemical analysis to assess ACE2 protein expression in the kidneys and found no ACEI-dependent effect ${ }^{43}$. Together, these 12 studies in humans imply a lack of association between ACE2 protein expression and the use of ARBs or ACEls and support the idea that ACEIs/ARBs are unlikely to raise ACE2 or be harmful in the context of COVID-19 infection.

\section{Discussion}

What would constitute strong, supportive evidence for the hypothesis that ACEI/ARB usage is a risk factor in the setting of SARS-CoV2 infection? Findings to help support that hypothesis would include: 1) Replication of a prominent effect in multiple animal studies and models; 2) Evidence that tissues with low expression of ACE2 have prominent increases in its expression and activity following ACEI/ARB treatment; 3) Data documenting that increases in ACE2 expression in response to ACEI/ARB treatment enhance the ability of the SARS-CoV-2 virus to infect cells; 4) Findings from human studies of statistically significant relationships between ACEI/ARB usage and ACE2 expression/activity; 5) Epidemiological data showing that COVID-19 patients administered ACEls/ARBs have increased morbidity and mortality, ideally with a dose-response relationship for such outcomes.

How well do the available data provide such evidence? 1) The hypothesis that ACE2 expression increases with ACEI/ARB use is not supported by the plurality of available data from animal studies. 2) There is no available evidence for de novo expression of ACE2 expression in response to ACEIs/ARBs in tissues with low expression. 3) The affinity of SARS-CoV-2 for ACE2 is very high, 4-fold greater than SARS-CoV-1 ${ }^{44}$ or higher; some studies suggest an order-of-magnitude higher affinity for SARS-CoV-2 ${ }^{45}$. It is unclear if small or modest perturbations in ACE2 expression impact the infectivity of SARS-COV-2. Moreover, ACE2 levels may decrease with age ${ }^{46,47}$ and diabetes ${ }^{48}$ yet elderly/diabetic subjects are more vulnerable than younger individuals to COVID-19 ${ }^{49}$. Modest changes in ACE2 expression (<2-fold, from most preclinical data discussed above) may not meaningfully impact on the high infectivity of SARS-CoV-2 in host tissues. 4) Data from human studies suggest that treatment with ACEIs/ARBs produces little or no effect on urinary or circulating ACE2 levels. As a caveat, changes in ACE2 levels in serum or urine may not reflect changes in tissue. 5) Epidemiological studies are largely unavailable in matched groups of patients infected with SARS-CoV-2, who have or have not been taking ACEIs/ARBs. One preliminary study, ${ }^{50}$ examined 28 patients with severe COVID-19 and 18 patients with mild disease, all of whom also had hypertension. ARB use was associated with a reduction in risk of severe COVID-19 disease, morbidity and mortality, a result that contradicts the hypothesis that ARB/ACEI use is harmful. However, only small numbers of patients have been assessed.

Based on the data summarized above, we conclude that current evidence, especially from human studies (Table 3), does not support the idea that treatment with ACEls or ARBS produces pathophysiologically relevant increases in ACE2 protein abundance. The hypothesis that the use of these drugs increases SARS-CoV-2 virus infectivity and/or severity of COVID-19 is therefore not supported by the available evidence. It would thus seem prudent for patients to continue receiving these medications, as recently recommended by multiple health associations $^{2}$ and other publications ${ }^{51}$. 
medRxiv preprint doi: https://doi.org/10.1101/2020.03.25.20043927; this version posted April 20, 2020. The copyright holder for this preprint (which was not certified by peer review) is the author/funder, who has granted medRxiv a license to display the preprint in perpetuity. It is made available under a CC-BY-ND 4.0 International license.

\section{Study Highlights}

What is the current knowledge on the topic?

Debate exists regarding the evidence for ACE inhibitor/ARB usage and expression levels of ACE2 protein. This is of concern in COVID-19 because ACE2 is the receptor for the SARS-CoV-2 virus.

\section{What question did this study address?}

We critically evaluated the evidence in the literature regarding the topic indicated above.

\section{What does this study add to our knowledge?}

This is the most comprehensive assessment of the evidence behind the hypothesis that ACEls/ARBs may be harmful in COVID-19, due to their up-regulation of ACE2 expression. We find that there is little evidence to justify these concerns. In particular, data from studies with human subjects refute the presence of a meaningful effect of ACE inhibitors or ARBs on the expression of ACE2 protein.

\section{How might this change clinical pharmacology or translational science?}

Concern has been raised regarding the administration of ACE inhibitors or ARBs to patients during the COVID-19 pandemic. Several articles have suggested that such drugs may be harmful, causing understandable confusion among patients and providers. We conclude that these concerns are not supported by available data and that clinicians should continue to prescribe and patients should continue to use these drugs for approved indications.

Author Contributions: KS compiled and analyzed data and wrote the manuscript. PAI wrote and edited the manuscript. 
medRxiv preprint doi: https://doi.org/10.1101/2020.03.25.20043927; this version posted April 20, 2020. The copyright holder for this preprint (which was not certified by peer review) is the author/funder, who has granted medRxiv a license to display the preprint in perpetuity. It is made available under a CC-BY-ND 4.0 International license .

\section{References}

1. Fang, L., Karakiulakis, G., \& Roth, M. (2020). Are patients with hypertension and diabetes mellitus at increased risk for COVID-19 infection? The Lancet Respiratory Medicine. 8(4), PE-21

2. Bozkurt, B., Kovacs, R., \& Harrington, B. (2020). HFSA/ACC/AHA Statement Addresses Concerns Re: Using RAAS Antagonists in COVID-19. American Heart Association Professional Heart Daily.

3. Phadke, M., \& Saunik, S. (2020). Rapid response: Use of angiotensin receptor blockers such as Telmisartan, Losartsan in nCoV Wuhan Corona Virus infections-Novel mode of treatment. Response to the emerging novel coronavirus outbreak. BMJ, 368, m406.

4. Lewis, E. (2020). ACE-inhibitors, ARBs and COVID-19: What GPs need to know. Royal Australian College of General Practitioners (RACGP) Feature, March 18, 2020

5. Patel, A. B., \& Verma, A. (2020). COVID-19 and Angiotensin-Converting Enzyme Inhibitors and Angiotensin Receptor Blockers: What Is the Evidence? JAMA. doi:10.1001/jama.2020.4812

6. Vaduganathan, M., Vardeny, O., Michel, T., McMurray, J. J., Pfeffer, M. A., \& Solomon, S. D. (2020). ReninAngiotensin-Aldosterone System Inhibitors in Patients with Covid-19. New England Journal of Medicine. doi: 10.1056/NEJMsr2005760

7. Li, G., Hu, R., \& Zhang, X. (2020). Antihypertensive treatment with ACEI/ARB of patients with COVID-19 complicated by hypertension. Hypertension Research, 1-3. doi:10.1038/s41440-020-0433-1

8. Uhlén, M., Fagerberg, L., Hallström, B. M., Lindskog, C., Oksvold, P., Mardinoglu, A., ... \& Olsson, I. (2015). Tissue-based map of the human proteome. Science, 347(6220), 1260419.

9. Wang, G., Lai, F. M. M., Lai, K. B., Chow, K. M., Kwan, C. H. B., Li, K. T. P., \& Szeto, C. C. (2009). Discrepancy between intrarenal messenger RNA and protein expression of ACE and ACE2 in human diabetic nephropathy. American journal of nephrology, 29(6), 524-531.

10. Ferrario, C. M., Jessup, J., Gallagher, P. E., Averill, D. B., Brosnihan, K. B., Tallant, E. A., ... \& Chappell, M. C. (2005). Effects of renin-angiotensin system blockade on renal angiotensin-(1-7) forming enzymes and receptors. Kidney international, 68(5), 2189-2196.

11. Yang, Z., Yu, X., Cheng, L., Miao, L. Y., Li, H. X., Han, L. H., \& Jiang, W. P. (2013). Effects of enalapril on the expression of cardiac angiotensin-converting enzyme and angiotensin-converting enzyme 2 in spontaneously hypertensive rats. Archives of cardiovascular diseases, 106(4), 196-201.

12. Nair, A. B., \& Jacob, S. (2016). A simple practice guide for dose conversion between animals and human. Journal of basic and clinical pharmacy, 7(2), 27.

13. Ocaranza, M. P., Godoy, I., Jalil, J. E., Varas, M., Collantes, P., Pinto, M., ... \& Castro, P. (2006). Enalapril attenuates downregulation of angiotensin-converting enzyme 2 in the late phase of ventricular dysfunction in myocardial infarcted rat. Hypertension, 48(4), 572-578.

14. Hamming, I., Van Goor, H., Turner, A. J., Rushworth, C. A., Michaud, A. A., Corvol, P., \& Navis, G. (2008). Differential regulation of renal angiotensin-converting enzyme (ACE) and ACE2 during ACE inhibition and dietary sodium restriction in healthy rats. Experimental physiology, 93(5), 631-638.

15. Velkoska, E., Dean, R. G., Burchill, L., Levidiotis, V., \& Burrell, L. M. (2010). Reduction in renal ACE2 expression in subtotal nephrectomy in rats is ameliorated with ACE inhibition. Clinical Science, 118(4), 269279.

16. Han, S. X., He, G. M., Wang, T., Chen, L., Ning, Y. Y., Luo, F., ... \& Xu, D. (2010). Losartan attenuates chronic cigarette smoke exposure-induced pulmonary arterial hypertension in rats: possible involvement of angiotensin-converting enzyme-2. Toxicology and applied pharmacology, 245(1), 100-107. 
medRxiv preprint doi: https://doi.org/10.1101/2020.03.25.20043927; this version posted April 20, 2020. The copyright holder for this preprint (which was not certified by peer review) is the author/funder, who has granted medRxiv a license to display the preprint in perpetuity. It is made available under a CC-BY-ND 4.0 International license .

17. Wösten-van Asperen, R. M., Lutter, R., Specht, P. A., Moll, G. N., van Woensel, J. B., van der Loos, C. M., ... \& Bos, A. P. (2011). Acute respiratory distress syndrome leads to reduced ratio of ACE/ACE2 activities and is prevented by angiotensin-(1-7) or an angiotensin II receptor antagonist. The Journal of pathology, 225(4), 618-627.

18. Burrell, L. M., Burchill, L., Dean, R. G., Griggs, K., Patel, S. K., \& Velkoska, E. (2012). Chronic kidney disease: cardiac and renal angiotensin-converting enzyme (ACE) 2 expression in rats after subtotal nephrectomy and the effect of ACE inhibition. Experimental physiology, 97(4), 477-485.

19. Burchill, L. J., Velkoska, E., Dean, R. G., Griggs, K., Patel, S. K., \& Burrell, L. M. (2012). Combination reninangiotensin system blockade and angiotensin-converting enzyme 2 in experimental myocardial infarction: implications for future therapeutic directions. Clinical Science, 123(11), 649-658.

20. Zhang, Y., Li, B., Wang, B., Zhang, J., Wu, J., \& Morgan, T. (2014). Alteration of cardiac ACE2/Mas expression and cardiac remodelling in rats with aortic constriction. Chin J Physiol, 57(6), 335-342.

21. Li, Y., Zeng, Z., Li, Y., Huang, W., Zhou, M., Zhang, X., \& Jiang, W. (2015). Angiotensin-converting enzyme inhibition attenuates lipopolysaccharide-induced lung injury by regulating the balance between angiotensinconverting enzyme and angiotensin-converting enzyme 2 and inhibiting mitogen-activated protein kinase activation. Shock, 43(4), 395-404.

22. Wang, G., Zhang, Q., Yuan, W., Wu, J., \& Li, C. (2016). Enalapril protects against myocardial ischemia/reperfusion injury in a swine model of cardiac arrest and resuscitation. International journal of molecular medicine, 38(5), 1463-1473.

23. Israili, Z.H., 2000. Clinical pharmacokinetics of angiotensin II (AT 1) receptor blockers in hypertension. Journal of Human Hypertension, 14(1), pp.S73-S86.

24. Li, H., Liu, L., Xie, L., Gan, D. and Jiang, X., 2016. Effects of berberine on the pharmacokinetics of losartan and its metabolite EXP3174 in rats and its mechanism. Pharmaceutical biology, 54(12), pp.2886-2894.

25. Stockbridge, N., 2013. NDA 204308, Center for Drug Evaluation and Research https://www.accessdata.fda.gov/drugsatfda docs/nda/2013/2043080rig1s000MedR.pdf

26. Bi, B.T., Yang, Y.B., Ma, A.D., Lin, T., Lin, H.B., Yang, X.M. and Xu, J.P., 2012. The effect of candesartan on the pharmacokinetics of enalaprilat in nephrotic rats. Eur Rev Med Pharmacol Sci, 16(15), pp.2162-2170.

27. Song, J.C. and White, C.M., 2002. Clinical pharmacokinetics and selective pharmacodynamics of new angiotensin converting enzyme inhibitors. Clinical pharmacokinetics, 41(3), pp.207-224.

28. Guo, X., Meng, Q., Liu, Q., Wang, C., Mao, Q., Sun, H., Peng, J., Kaku, T. and Liu, K., 2012. Peptide cotransporter 1 in intestine and organic anion transporters in kidney are targets of interaction between JBP485 and lisinopril in rats. Drug metabolism and pharmacokinetics, 27(2), pp.232-241.

29. Dubey, R. and Ghosh, M., 2015. Simultaneous determination and pharmacokinetic study of losartan, losartan carboxylic acid, ramipril, ramiprilat, and hydrochlorothiazide in rat plasma by a liquid chromatography/tandem mass spectrometry method. Scientia pharmaceutica, 83(1), pp.107-124.

30. Ganten, D. and Mulrow, P.J. eds., 2012. Pharmacology of antihypertensive therapeutics. Springer Science \& Business Media.

31. Wei, J., Ma, W., Yao, G., Jia, Q., Cheng, X., Ouyang, H., Chang, Y., Chen, X. and He, J., 2019. A High Throughput HPLC-MS/MS Method for Antihypertensive Drugs Determination in Plasma and Its Application on Pharmacokinetic Interaction Study with Shuxuetong Injection in Rats. BioMed research international, 2019. 
medRxiv preprint doi: https://doi.org/10.1101/2020.03.25.20043927; this version posted April 20, 2020. The copyright holder for this preprint (which was not certified by peer review) is the author/funder, who has granted medRxiv a license to display the preprint in perpetuity. It is made available under a CC-BY-ND 4.0 International license .

32. Mizuiri, S., Aoki, T., Hemmi, H., Arita, M., Sakai, K., \& Aikawa, A. (2011). Urinary angiotensin-converting enzyme 2 in patients with CKD. Nephrology, 16(6), 567-572.

33. Furuhashi, M., Moniwa, N., Mita, T., Fuseya, T., Ishimura, S., Ohno, K., ... \& Ohnishi, H. (2015). Urinary angiotensin-converting enzyme 2 in hypertensive patients may be increased by olmesartan, an angiotensin II receptor blocker. American journal of hypertension, 28(1), 15-21.

34. Liang, Y., Deng, H., Bi, S., Cui, Z., Lata, A., Zheng, D., \& Wang, Y. (2015). Urinary angiotensin converting enzyme 2 increases in patients with type 2 diabetic mellitus. Kidney and Blood Pressure Research, 40(2), 101110.

35. Mariana, C. P., Ramona, P. A., Ioana, B. C., Diana, M., Claudia, R. C., Stefan, V. D., \& Maria, K. I. (2016). Urinary angiotensin converting enzyme 2 is strongly related to urinary nephrin in type 2 diabetes patients. International urology and nephrology, 48(9), 1491-1497.

36. Epelman, S., Tang, W. W., Chen, S. Y., Van Lente, F., Francis, G. S., \& Sen, S. (2008). Detection of soluble angiotensin-converting enzyme 2 in heart failure: insights into the endogenous counter-regulatory pathway of the renin-angiotensin-aldosterone system. Journal of the American College of Cardiology, 52(9), 750-754.

37. Soro-Paavonen, A., Gordin, D., Forsblom, C., Rosengard-Barlund, M., Waden, J., Thorn, L., ... \& FinnDiane Study Group. (2012). Circulating ACE2 activity is increased in patients with type 1 diabetes and vascular complications. Journal of hypertension, 30(2), 375-383.

38. Ortiz-Perez, J. T., Riera, M., Bosch, X., De Caralt, T. M., Perea, R. J., Pascual, J., \& Soler, M. J. (2013). Role of circulating angiotensin converting enzyme 2 in left ventricular remodeling following myocardial infarction: a prospective controlled study. PLoS One, 8(4).

39. Anguiano, L., Riera, M., Pascual, J., Valdivielso, J. M., Barrios, C., Betriu, A., ... \& Castro, E. (2015). Circulating angiotensin-converting enzyme 2 activity in patients with chronic kidney disease without previous history of cardiovascular disease. Nephrology Dialysis Transplantation, 30(7), 1176-1185.

40. Úri, K., Fagyas, M., Kertész, A., Borbély, A., Jenei, C., Bene, O., ... \& Tóth, A. (2016). Circulating ACE2 activity correlates with cardiovascular disease development. Journal of the Renin-Angiotensin-Aldosterone System, 17(4), 1470320316668435.

41. Walters, T. E., Kalman, J. M., Patel, S. K., Mearns, M., Velkoska, E., \& Burrell, L. M. (2017). Angiotensin converting enzyme 2 activity and human atrial fibrillation: increased plasma angiotensin converting enzyme 2 activity is associated with atrial fibrillation and more advanced left atrial structural remodelling. Ep Europace, 19(8), 1280-1287.

42. Ramchand, J., Patel, S. K., Srivastava, P. M., Farouque, O., \& Burrell, L. M. (2018). Elevated plasma angiotensin converting enzyme 2 activity is an independent predictor of major adverse cardiac events in patients with obstructive coronary artery disease. PloS one, 13(6).

43. Lely, A. T., Hamming, I., van Goor, H., \& Navis, G. J. (2004). Renal ACE2 expression in human kidney disease. The Journal of Pathology: A Journal of the Pathological Society of Great Britain and Ireland, 204(5), 587-593.

44. Walls, A. C., Park, Y. J., Tortorici, M. A., Wall, A., McGuire, A. T., \& Veesler, D. (2020). Structure, function, and antigenicity of the SARS-CoV-2 spike glycoprotein. Cell.

45. Shang, J., Ye, G., Shi, K., Wan, Y., Luo, C., Aihara, H., Geng, Q., Auerbach, A. and Li, F., 2020. Structural basis of receptor recognition by SARS-CoV-2. Nature, pp.1-8.

46. Xudong, X., Junzhu, C., Xingxiang, W., Furong, Z., \& Yanrong, L. (2006). Age-and gender-related difference of ACE2 expression in rat lung. Life sciences, 78(19), 2166-2171. 
medRxiv preprint doi: https://doi.org/10.1101/2020.03.25.20043927; this version posted April 20, 2020. The copyright holder for this preprint (which was not certified by peer review) is the author/funder, who has granted medRxiv a license to display the preprint in perpetuity. It is made available under a CC-BY-ND 4.0 International license.

47. Schulman, I. H., Zhou, M. S., Treuer, A. V., Chadipiralla, K., Hare, J. M., \& Raij, L. (2010). Altered renal expression of angiotensin II receptors, renin receptor, and ACE-2 precede the development of renal fibrosis in aging rats. American journal of nephrology, 32(3), 249-261.

48. Li, X. C., Zhang, J., \& Zhuo, J. L. (2017). The vasoprotective axes of the renin-angiotensin system: Physiological relevance and therapeutic implications in cardiovascular, hypertensive and kidney diseases. Pharmacological research, 125, 21-38.

49. Zhou, F., Yu, T., Du, R., Fan, G., Liu, Y., Liu, Z., ... \& Guan, L. (2020). Clinical course and risk factors for mortality of adult inpatients with COVID-19 in Wuhan, China: a retrospective cohort study. The Lancet. 395( 10229), P1054-1062

50. Liu, Y., Huang, F., Xu, J., Yang, P., Qin, Y., Cao, M., ... \& Lv, J. (2020). Anti-hypertensive Angiotensin II receptor blockers associated to mitigation of disease severity in elderly COVID-19 patients. medRxiv. doi: https://doi.org/10.1101/2020.03.20.20039586

51. Danser, A. J., Epstein, M., \& Batlle, D. (2020). Renin-Angiotensin System Blockers and the COVID-19 Pandemic: At Present There Is No Evidence to Abandon Renin-Angiotensin System Blockers. Hypertension, HYPERTENSIONAHA-120. 
medRxiv preprint doi: https://doi.org/10.1101/2020.03.25.20043927; this version posted April 20, 2020. The copyright holder for this preprint

(which was not certified by peer review) is the author/funder, who has granted medRxiv a license to display the preprint in perpetuity. It is made available under a CC-BY-ND 4.0 International license .

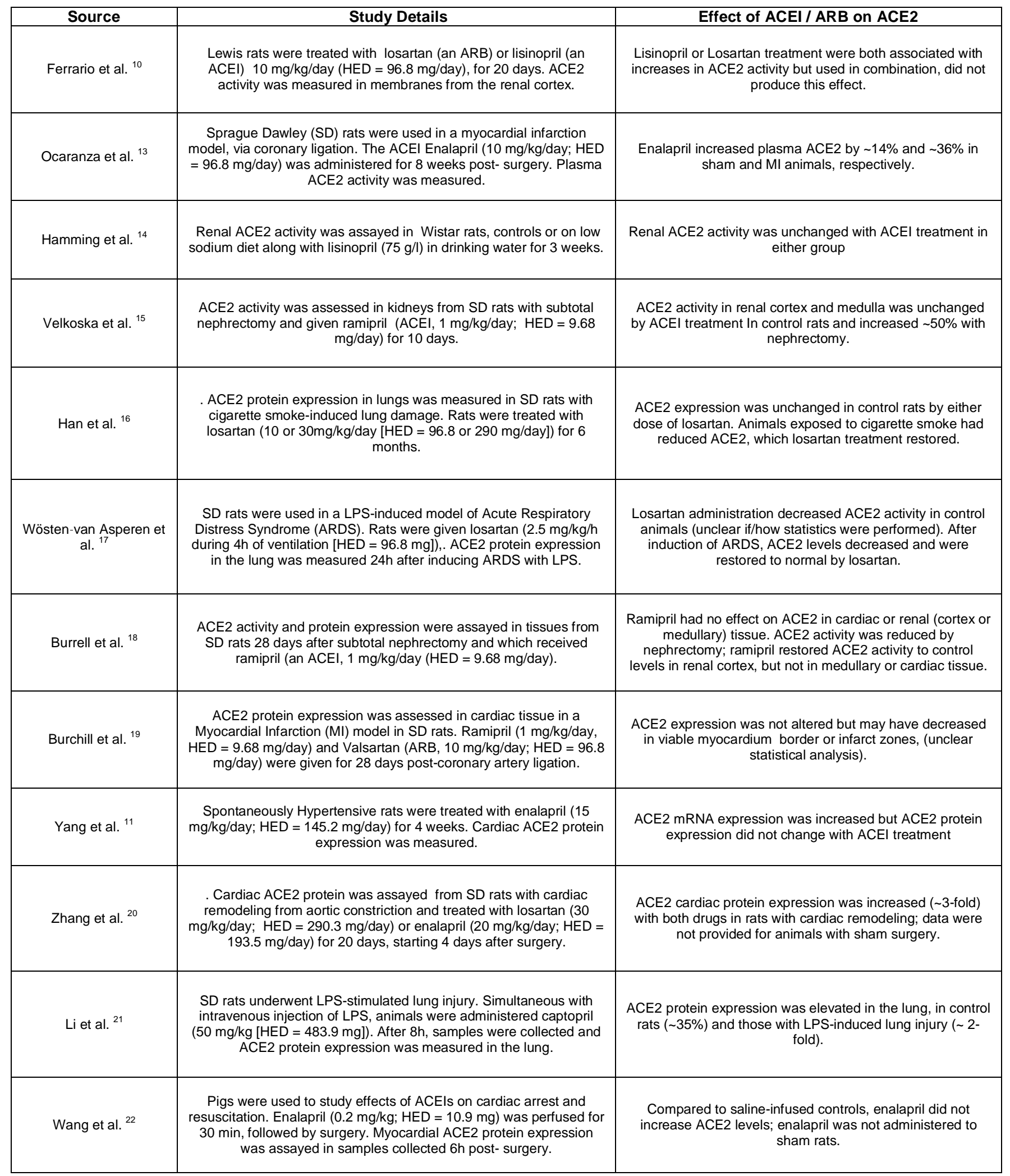

Table 1. Studies in animals that have assessed ACE2 protein expression in response to ACEI/ARB treatment. 
medRxiv preprint doi: https://doi.org/10.1101/2020.03.25.20043927; this version posted April 20, 2020. The copyright holder for this preprint (which was not certified by peer review) is the author/funder, who has granted medRxiv a license to display the preprint in perpetuity.

It is made available under a CC-BY-ND 4.0 International license.

Table 2. FDA-recommended doses of the ACEIs/ARBs discussed in Table 1, along with pharmacokinetics data in humans and rats.

\begin{tabular}{|c|c|c|c|c|}
\hline Drug & $\begin{array}{l}\text { Typical initial } \\
\text { daily adult dose }\end{array}$ & $\begin{array}{l}\text { Maximum daily adult } \\
\text { dose }\end{array}$ & $\mathrm{C}_{\max }$ in humans & $\mathrm{C}_{\max }$ in rats \\
\hline Losartan & $50 \mathrm{mg}$ & $100 \mathrm{mg}$ & $250 \mathrm{ng} / \mathrm{ml}$, for $50 \mathrm{mg}$ dose ${ }^{23}$ & $\begin{array}{c}1260 \mathrm{ng} / \mathrm{ml} \text {, for } 10 \mathrm{mg} / \mathrm{kg} \text { dose; } \\
\mathrm{HED}=96.8 \mathrm{mg}\end{array}$ \\
\hline Enalapril & $5 \mathrm{mg}$ & $40 \mathrm{mg}$ & $62 \mathrm{ng} / \mathrm{ml}$ for $10 \mathrm{mg}$ dose ${ }^{25}$ & $\begin{array}{c}1329 \mathrm{ng} / \mathrm{ml} \text { for } 15 \mathrm{mg} / \mathrm{kg}_{\text {g }} \text { dose; } \\
\mathrm{HED}=145.2 \mathrm{mg}\end{array}$ \\
\hline Lisinopril & $10 \mathrm{mg}$ & $40 \mathrm{mg}$ & $38 \mathrm{ng} / \mathrm{ml}$ for $10 \mathrm{mg}^{27}$ & $\begin{array}{c}6400 \mathrm{ng} / \mathrm{ml} \text { for } 5 \mathrm{mg} / \mathrm{kg} \text { dose; HED } \\
=48.4 \mathrm{mg}\end{array}$ \\
\hline Ramipril & $2.5 \mathrm{mg}$ & $20 \mathrm{mg}$ & $52.2 \mathrm{ng} / \mathrm{ml}$ at $10 \mathrm{mg}$ dose ${ }^{27}$ & $\begin{array}{c}50.45 \mathrm{ng} / \mathrm{ml} \text { for } 1 \mathrm{mg} / \mathrm{kg} \text { dose; } \\
\mathrm{HED}=9.68 \mathrm{mg}\end{array}$ \\
\hline Captopril & $50 \mathrm{mg}$ & $450 \mathrm{mg}$ & $1580 \mathrm{ng} / \mathrm{ml}$ for $100 \mathrm{mg}$ dose ${ }^{30}$ & $\begin{array}{c}9200 \mathrm{ng} / \mathrm{ml} \text { for } 30 \mathrm{mg} / \mathrm{kg} \text { dose; } \\
\mathrm{HED}=290.4 \mathrm{mg}\end{array}$ \\
\hline Valsartan & $80 \mathrm{mg}$ & $320 \mathrm{mg}$ & $2000 \mathrm{ng} / \mathrm{ml}$ for $80 \mathrm{mg}$ dose ${ }^{23}$ & $\begin{array}{c}\sim 3700 \mathrm{ng} / \mathrm{ml} \text { for } 4.71 \mathrm{mg} / \mathrm{kg} \text { dose; } \\
\mathrm{HED}=45.6 \mathrm{mg}^{31}\end{array}$ \\
\hline
\end{tabular}


medRxiv preprint doi: https://doi.org/10.1101/2020.03.25.20043927; this version posted April 20, 2020. The copyright holder for this preprint (which was not certified by peer review) is the author/funder, who has granted medRxiv a license to display the preprint in perpetuity. It is made available under a CC-BY-ND 4.0 International license .

Table 3: Studies in humans of the relationship between ACEI/ARB use and ACE2 protein expression. Entries are

\begin{tabular}{|c|c|c|}
\hline Source & Details of Study & Effect of ACEI / ARB on ACE2 \\
\hline Mizuiri et al., ${ }^{32}$ & $\begin{array}{c}\text { Urinary ACE2 protein levels were measured in } \\
190 \text { patients with chronic kidney disease and } 36 \\
\text { healthy subjects. }\end{array}$ & $\begin{array}{l}\text { No significant difference in urinary ACE2 was } \\
\text { observed in response to treatment with ACEI } \\
\text { and ARB }\end{array}$ \\
\hline Furuhashi et al., ${ }^{33}$ & $\begin{array}{c}\text { Urinary ACE2 protein concentration was assayed } \\
\text { in } 617 \text { subjects, including } 101 \text { subjects who did } \\
\text { not use any medication and } 100 \text { hypertensives } \\
\text { treated with various drugs. }\end{array}$ & $\begin{array}{l}\text { Enalapril, losartan, valsartan, candesartan, } \\
\text { valsartan and telmisartan had no effect. } \\
\text { Olmesartan increased urinary ACE2. }\end{array}$ \\
\hline Liang et al., ${ }^{34}$ & $\begin{array}{c}\text { Urinary ACE2 protein concentration was assessed } \\
\text { in } 132 \text { Type- } 2 \text { Diabetic patients and } 34 \text { healthy } \\
\text { volunteers. }\end{array}$ & $\begin{array}{c}\text { Patients with hypertension had a } \sim 40 \% \\
\text { decrease in urinary ACE2 if treated with } \\
\text { inhibitors of renin-angiotensin signaling, } \\
\text { compared to hypertensive patients not taking } \\
\text { such medications. }\end{array}$ \\
\hline Mariana et al., ${ }^{35}$ & $\begin{array}{l}\text { Urinary ACE2 protein levels were measured via } \\
\text { ELISA in } 75 \text { patients with Type- } 2 \text { diabetes }\end{array}$ & $\begin{array}{c}\text { Use of ARBs or ACEls had no effect on } \\
\text { urinary ACE2 levels }\end{array}$ \\
\hline Epelman et al., ${ }^{36}$ & $\begin{array}{c}\text { Plasma ACE2 activity was assayed from } 228 \\
\text { patients with heart failure. }\end{array}$ & $\begin{array}{l}\text { No association was found between } \\
\text { ACEI/ARB use and ACE2 levels. }\end{array}$ \\
\hline $\begin{array}{l}\text { Soro-Paavonen et } \\
\text { al., }{ }^{37}\end{array}$ & $\begin{array}{c}\text { Serum ACE2 activity was measured in } 859 \\
\text { patients with Type-1 Diabetes and } 99 \text { healthy } \\
\text { control subjects. }\end{array}$ & $\begin{array}{l}\text { ACE2 was increased } \\
\sim 10 \text { to } 20 \% \text { (higher in women) in diabetics } \\
\text { using ACEls. No association was found } \\
\text { between ARB usage and ACE2 levels. }\end{array}$ \\
\hline Ortiz-Perez et al. ${ }^{38}$ & $\begin{array}{c}\text { Serum ACE2 activity was assayed in } 95 \text { patients } \\
\text { with ST-elevation myocardial infarction and } 22 \\
\text { control subjects. }\end{array}$ & $\begin{array}{c}\text { No association was found between ACEI use } \\
\text { and ACE2 levels. ARB usage was not } \\
\text { discussed. }\end{array}$ \\
\hline Anguiano et al., ${ }^{39}$ & $\begin{array}{l}\text { Plasma ACE2 activity was measured in } n=568 \\
\text { control subjects, } n=1458 \text { with stage } 3-5 \text { chronic } \\
\text { kidney disease and } n=546 \text { patients on dialysis. } \\
\text { Multivariate regression analysis was performed to } \\
\text { identify which factors influenced ACE2. }\end{array}$ & $\begin{array}{c}\text { ACEI use had no effect on ACE2 in any } \\
\text { group. ARB use did not predict ACE2 activity } \\
\text { in control or stage } 3-5 \text { patients; in patients on } \\
\text { dialysis ARB use had a small effect raising } \\
\text { ACE2 activity. }\end{array}$ \\
\hline Uri et al., ${ }^{40}$ & $\begin{array}{c}\text { Serum ACE2 activity was assayed in } 141 \text { healthy } \\
\text { subjects, } 239 \text { hypertensive patients, and } 188 \\
\text { patients with heart failure of different types. }\end{array}$ & $\begin{array}{c}\text { Logistic regression analysis showed that } \\
\text { ACEI and ARB usage had no association with } \\
\text { ACE2 levels }\end{array}$ \\
\hline Walters et al., ${ }^{41}$ & $\begin{array}{l}\text { Plasma ACE2 activity was assessed in } 25 \text { control } \\
\text { subjects and } 88 \text { patients with atrial fibrillation. }\end{array}$ & $\begin{array}{l}\text { No association was found between ACE2 } \\
\text { levels and ACEI/ARB use. }\end{array}$ \\
\hline $\begin{array}{l}\text { Ramchand } \\
\text { et al., }\end{array}$ & $\begin{array}{l}\text { Plasma ACE2 activity was measured in } 79 \\
\text { patients with obstructive coronary artery disease. }\end{array}$ & $\begin{array}{l}\text { ACE2 levels had no association with use of } \\
\text { ACEls or ARBs }\end{array}$ \\
\hline
\end{tabular}

ordered chronologically, first for studies in urine and then for studies in circulating ACE2. 